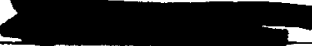 \\ (CLASSIFICATION)}

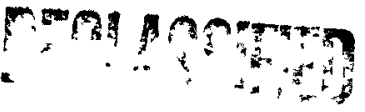

\section{GENERAL (GLCTRIC}

HANFORD ATOMIC PRODUCTS OPERATION - RICHLAND, WASHINGTON
$H W-51655$

SERIES AND COPY NO.

A. 12

DATE

July 19, 1957

\section{RESTRICTED DATA}

AHIS DOCUMENT CONTAINS RESTRICTED DATA AS DEFINED IN THE ATOMIC ENERGY ACT OF 1954. ITS TRANSMITTAL OR THE DISCLOSURE OF ITS CONTENTS IN ANY MANNER TO AN UNAUTHORIZED PERSON IS PROHIEITED.

\section{OTHER OFFICIAL CLASSIFIED INFORMATION}

THIS MATERIAL CONTAINS INFORMATION AFFECTING THE NATIONAL DEFENSE OF THE UNITED STATES WITHIN THE MEANING OF THE ESPIONAGE LAWS, TITLE 18, U.S.C, SECS. 793 AND 794, THE TRANSMISSION OR REVELATION OF WHICH IN ANY MANNER TO AN UNAUTHORIZED PERSON IS PROHIBITED BY LAW.
TITLE

OXIDATION OF PLUTONIUM(III)

BY SODIUM NTTRITE

\section{AUTHOR}

A. Brunstad

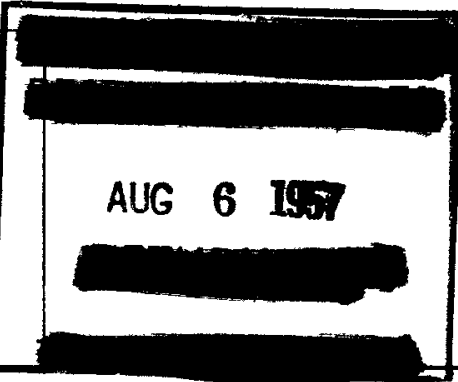

THIS DOCUMENT MUST NOT BE LEFT UNATTENDED OR WHERE AN UNAUTHORIZED PERSON MAY HAVE ACCESS TO IT. WHEN NOT IN USE, IT MUST BE STORED IN AN APPROVED LOCKED REPOSITORY WITHIN AN APPROVED GUARDED AREA. WHILE IT IS YOUR POSSESSION AND UNTIL YOU HAVE OBTAINED A SIGNED RECEIPT FROM CLASSIFIED FILES, IT IS YOUR RESPONSIBILITY TO KEEP IT AND ITS CONTENTS WITHIN THE LIMITS OF THIS PROJECT AND FROM ANY UNAUTHORIZED PERSON. ITS TRANSMITTAL TO, AND STORAGE AT YOUR PLACE OF RESIDENCE IS PROHIBITED. IT IS NOT TO BE DUPLICATED. IF ADDITIONAL COPIES ARE REQUIRED, OBTAIN THEM FROM THE RELATED ISSUING FILE. ALL PERSONS READING THIS DOCUMENT ARE REQUESTED TO SIGN IN THE SPACE PROVIDED BELOW.

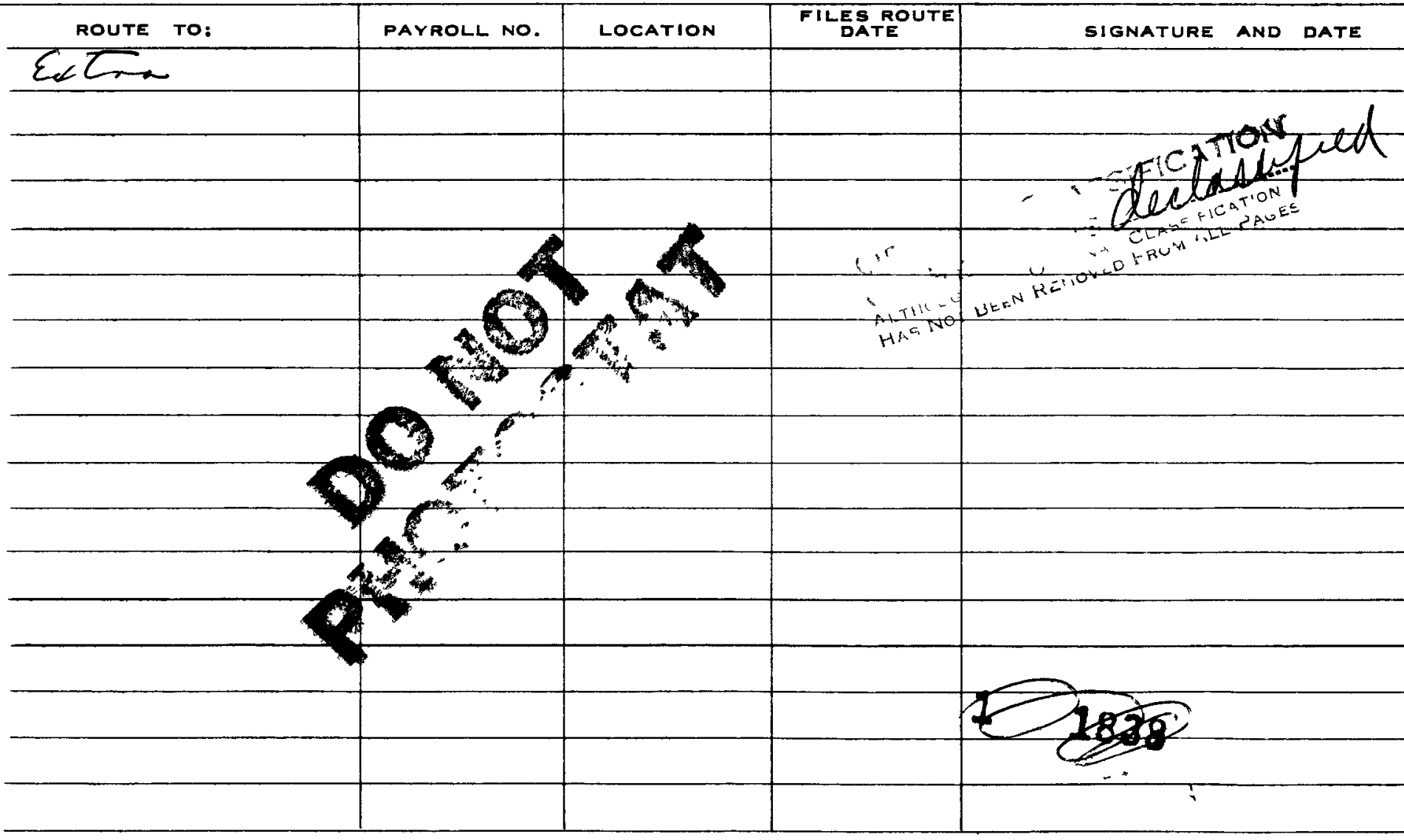

C-3195-MS (7 - 55) AEC GE NICHLAND WASH

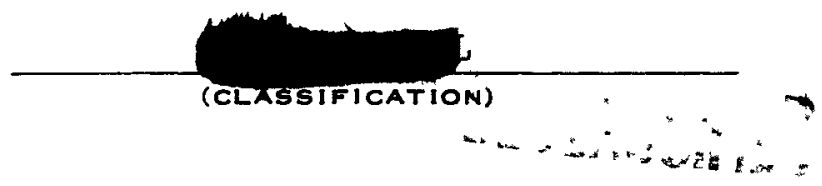




\section{DISCLAIMER}

This report was prepared as an account of work sponsored by an agency of the United States Government. Neither the United States Government nor any agency Thereof, nor any of their employees, makes any warranty, express or implied, or assumes any legal liability or responsibility for the accuracy, completeness, or usefulness of any information, apparatus, product, or process disclosed, or represents that its use would not infringe privately owned rights. Reference herein to any specific commercial product, process, or service by trade name, trademark, manufacturer, or otherwise does not necessarily constitute or imply its endorsement, recommendation, or favoring by the United States Government or any agency thereof. The views and opinions of authors expressed herein do not necessarily state or reflect those of the United States Government or any agency thereof. 


\section{DISCLAIMER}

Portions of this document may be illegible in electronic image products. Images are produced from the best available original document. 


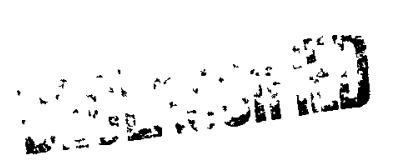

This document classified by

A. Brunstad
This document consists of 12 pages. Copy No. 14 of 19 copies. Series

\title{
OXIDATION OF PLUTONTUM(III) BY SODIUM NITRITE
}

\author{
By \\ A. Brunstad \\ 234-5 Development Operation \\ Research and Engineering Operation \\ jox3ors.

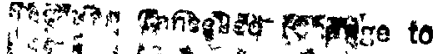 \\ bets \\ A. Brunstad \\ By \\ Lxto he k2s?

$$
\text { July } 17,1957
$$
HANFORD ATOMIC PRODUCTS OPERAT ION
RICHIAND, WASHINGTON \\ Operated for the Atomic Energy Commission by the
}

General Electric Company under Contract \#W-31-109-Eng-52

\begin{abstract}
AmEPORT
This report was prepared only for use within General Electric Company in the course of work under Atomic Energy Commission Contract W-31-109-Eng-52. Any views or opinions expressed in the report are those of the authors only.
\end{abstract}

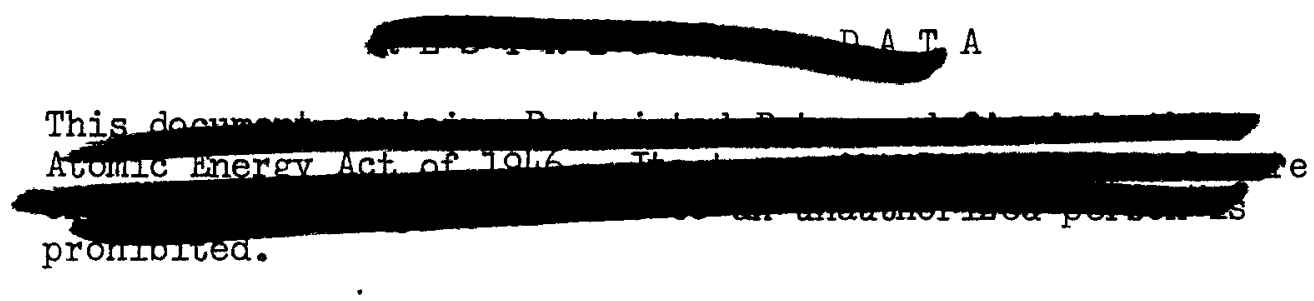

an. ‥ 
INTERNAL DISTRIBUTION
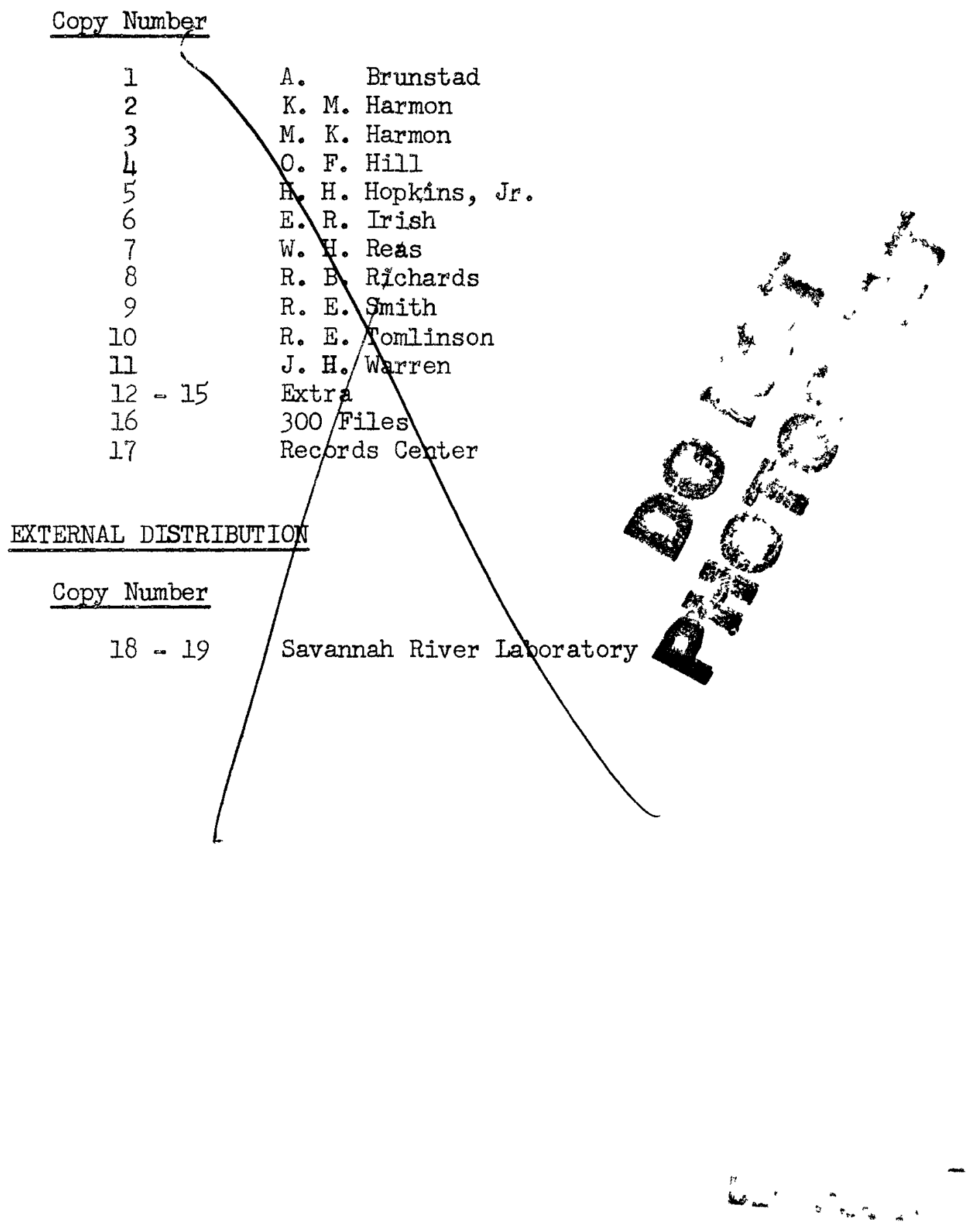
I. INTRODUCTION

The oxidation of plutonium(III) to plutonium(IV) by nitrite has been studied by solvent extraction methods and found to be very rapid.(1) (2) (3) The speed of the reaction has discouraged attempts to measure the reaction velocity con. stant by means of spectrophotometry and specific values of this constant were not available previously. Interest here is in the kinetics of the oxidation of plutonium(III) to plutonium(IV) in nitric acid solution containing ferrous sulfamate. The ferrous sulfamate yields sulfate ions when oxidized by the nitrite. The electrochemical potentials indicate oxidation of plutonium(IV) to be complete in the presence of sulfate. (3) The velocity $r$ ate constant for the oxidation of plutonium(III) in this system has been determined to provide information for the design of equipment employing this reaction.

\section{SUMMARY}

The reaction velocity constant for the oxidation of plutonium(III) by nitrite in nitric acid solution containing ferrous sulfamate is given. The reaction rate was found to be measurable by means of spectrophotometry. The data indicate the reaction to be a pseudo first-order reaction in the region of nitric acid and nitrite concentration of interest. The reaction velocity constant, expressed as a first-order reaction with respect to plutonium, was found for several values of nitric acid and nitrite concentrations. The nitric acidareaction velocity constant relationship is given.

The oxidation of the ferrous sulfamatesplutonium(III) solution proceeds successively through the sulfamate, ferrous, and plutonium(III) ions. An autocatalytic mechanism is associated with the oxidation of both ferrous and plutonium ions which obviates the possibility of simple calculations of constants based on nitrite concentration. An empirical relationship between the reaction velocity constant and the (added) nitrite concentration is given.

\section{DISCUSSION}

The Beckman DK-2 ratio recording spectrophotometer was used to follow the course of the reaction. $\mathrm{A} 1.6 \mathrm{M} \mathrm{NaNO}_{2}$ solution was used to oxidize the ferrous sulfamate-plutonium(III) solution. The starting ferrous sulfamate concentration was $0.024 \mathrm{M}$ in all experiments. The sodium nitrite solution was introduced into the reduce $\bar{d}$ plutonium solution in the spectrophotometer cell and immediately stirred with a pipette. Care was taken not to introduce air while stirring. Absor bence readings were taken at $1 / 2$ or 1 minute intervals until near com. pletion of the reaction. The $600 \mathrm{mp}$ plutonium(III) absorbence peak was used to measure the reaction rate; however, several checks were made by measuring the growth of the $475 \mathrm{mp}$ plutonium(IV) peak. Only this part of the spectrum was scanned.

The reaction rate was determined at several acidity values within the range $0.4 \mathrm{M}$ to $2.0 \mathrm{M} \mathrm{HNO}_{3}$. Starting concentrations from $0.04 \mathrm{M}$ to $0.1 \mathrm{M}$ were employed in determining the nitrite concentration effect.

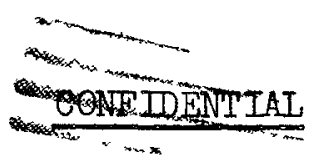


Timing of the spectrum scanning was done such that the indicated time lapse refers to the period from addition of the nitrite to the time indicated by the top of the $600 \mathrm{mp}$ plutonium(III) peak. Approximate plutonium(III) con. centrations were calculated from absorbence at this wave length. Simultaneous values for plutonium(IV) formed in the oxidation were obtained by difference between the plutonium(III) values and starting (total) plutonium concentration. These plutonium(IV) concentrations and established plutonium(IV) molar absorbence values at $600 \mathrm{mp}$ were then used to calculate the contribution due to plutonium(IV) at the $600 \mathrm{mp}$ plutonium(III) peak. This plutonium(IV) contric bution subtracted from the first plutonium(III) estimate gave the plutonium(III) concentration figures used in subsequent plots and calculations. Semilog plots of these data ( $C$ vs $t$ ) are shown. Convenient points were taken from these lines to calculate the rate constant $k$.

The disappearance (oxidation) of plutonium(III) is represented by the statement for a unimolecular reaction:

$$
\frac{\infty \mathrm{d}[\mathrm{Pu}(\mathrm{III})]}{\mathrm{dt}}=\mathrm{k}[\mathrm{Pu}(\mathrm{III})]
$$

Values of $k$ were calculated from the integrated form:

$$
k=\frac{2.303}{t_{2}-t_{1}} \log \frac{C_{1}}{C_{2}}
$$

Constant values of $\mathrm{k}$ indicated the above expression to be satisfactory. This is also evident from the straight lines shown in semi-log plots, Figures 4 and 6. The effect of nitric acid variations is shown by sample spectra in Figures 1, 2, and 3. Figure 1 illustrates the delay period found at low acidity. The high general absorbence during the first three to four minutes is due to the continued liberation of nitrogen gas during the sulfamate oxidation.

$$
\mathrm{HNO}_{2}+\mathrm{NH}_{2} \mathrm{SO}_{3}-\rightarrow \mathrm{N}_{2}+\mathrm{HSO}_{4}-+\mathrm{H}_{2} \mathrm{O}
$$

At higher acidities, this gas evolution is nearly instantaneous and is complete before scanning is started. It may be seen that the height of the $600 \mathrm{m \mu}$ plutonium(III) peak, above general absorbence, does not diminish nor is there a growth of the $475 \mathrm{mp}$ plutonium(IV) peak until liberation of gas is complete. Concentrations of plutonium(III) calculated from the spectra subsequent to gas liberation are shown at the right with a separate time axis in Figure 4. The first point does not fall on the straight line, indicating a slower reaction rate at first and a rate dependency on factors other than plutonium(III) concentration. Figure 5 is a plot of $k$ vs nitric acid concentration. The nitric acid dependency of the reaction is linear in the range $0.5 \mathrm{M}$ to $2.0 \mathrm{M}$ acid and may be expressed:

$$
\mathrm{k}=0.009+0.006 \mathrm{H}^{+}
$$

Generalization of this expression beyond the conditions and range indicated are probably not warranted.

Figure 6 is a plot of data from the spectra shown in Figures 9 to 13 inclusive. The reaction at $0.04 \mathrm{MNNO}_{2}$, Figure 8 , is not measurable. The curves

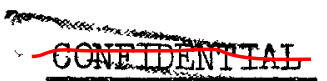




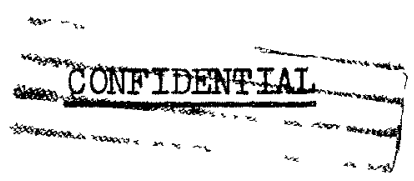

representing the four highest nitrite concentrations again showed the rate to be mainly dependent on plutonium concentration. The shape of the curve representing oxidation with $0.053 \mathrm{M} \mathrm{NaNO}_{2}$ would indicate that the specific reaction rate increased during the reaction. This is similar to the phenomena observed at low acidity. Both are explained on the bases of the autocatalytic mechanism of oxidation of irgn and plufonium. Nitrogen dioxide has been shown to be the effective oxidant. (4) (5) (6)

The concentration of $\mathrm{NO}_{2}$ is controlled by the following rapidly reversible reaction:

$$
2 \mathrm{HNO}_{2} \rightleftarrows \mathrm{NO}_{2}+\mathrm{NO}+\mathrm{H}_{2} \mathrm{O}
$$

That the oxidation of plutonium(III) to plutonium(IV) actually results in an increase in oxidant may be seen from the following reactions:

$$
\begin{aligned}
& \mathrm{Pu}(\mathrm{III})+\mathrm{NO}_{2} \rightarrow \mathrm{Pu}(\mathrm{IV})+\mathrm{NO}_{2}^{-} \\
& \mathrm{H}^{+}+\mathrm{NO}_{2}^{-} \rightarrow \mathrm{HNO}_{2} \\
& \mathrm{HNO}_{2}+\mathrm{H}^{+}+\mathrm{NO}_{3}^{-} \rightarrow 2 \mathrm{NO}_{2}+\mathrm{H}_{2} \mathrm{O}
\end{aligned}
$$

Thus each plutonium atom oxidized adds one $\mathrm{NO}_{2}$ molecule.

The reaction with iron and with plutonium are taken to be of identical mechanism. The above mechanism provides oxidant at high enough concentration to make the oxidation of plutonium appear dependent only on its own concentration. However, at low nitric acid and at low sodium nitrite concentrations there is a delay in establishing this condition, but even under the se condim tions, the reaction $r$ ate appears to become plutonium concentration dependent only.

The $0.024 \mathrm{M}$ ferrous sulfamate requires an $0.048 \mathrm{M}$ concentration of sodium nitrite for oxidation of the sulfamic acid only. The $0.04 \mathrm{M} \mathrm{NaNO}$, Figure 8 , is, therefore, insufficient to oxidize the sulfamic acid, and oxidation of iron and plutonium is not accomplished. The $0.053 \mathrm{M}$ added nitrite, Figure 9, is sufficient to oxidize the sulfamate and part of the iron, thus starting the antocatalytic mechanism, and effecting oxidation of iron and plutonium. The shape of the curve representing this concentration of added nitrite, Figure 6, in dicates increasing reaction velocity during the first one and onewhalf minutes, which may be explained by the buildmup of oxidant by the autocatalytic mechanism. The last three points of this curve form a nearly straight line, indicating the reaction has become mainly plutonium concentration dependent. The higher concentrations of added sodium nitrite, Figure 6, yielded unchanging values for the reaction velocity constant throughout the course of each reaction.

The values of $k$ found at various added nitrite concentrations ( $\mathrm{M}_{t_{0}}$ ) produced a straight line when plotted on semilog paper (Figure 7). This graph is most convenient in evaluating the effect of added nitrite concentration on the reaction velocity. This graph indicates the reaction velocity constant may be related to the starting nitrite concentration by an expression of the type:

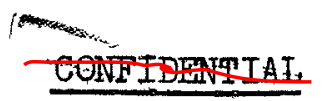




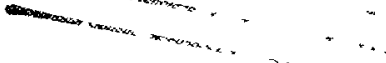

$k=a c^{b C\left(\mathrm{NaNO}_{2}\right)}$

The slope and intercept of the line was used to obtain the expression

$\log \mathrm{k}=6.4 I\left(\mathrm{NaNO}_{2}\right)+\log 0.004$

where $k$ is in $\sec ^{-1}$.

IV. BIBLIOGRAPHY

1. Thomas, J. R. and H.W. Crandall, The Chelate Process, TID-10002, December 12, 1946 (Unclassified); pp. 30-34.

2. Wilson, A. S. and T. I. Swanson, A Continuous Process for the Oxidation of the Purex IBP Stream, HW-23301, January 17, 1952 (Secret)。

3. Reilly, V.J., Purex Process Plutonium Oxidation and Reduction, August 10 to Nopember $10,195 I_{2} C F=5 I-11-140$ (Secret).

4. Zebroski, E., and R. C. Feber, Sulfamic Acid In The Redox Process, KAPL 89 (Confidential).

5. Yost, D. M. and H. Russell, Jr., Sustematic Inorganic Chemistry. New York: Prentice.Hall, Inc., 1946, pp. 58.61.

6. Connick, R. E., Oxidation States, Potentials, Equilibria, and Oxidation Reduction Reactions of Plutonium. National Nuclear Energy Series IV-14A McGraw-Hill Book Company, Inc., 1954, p 272. 

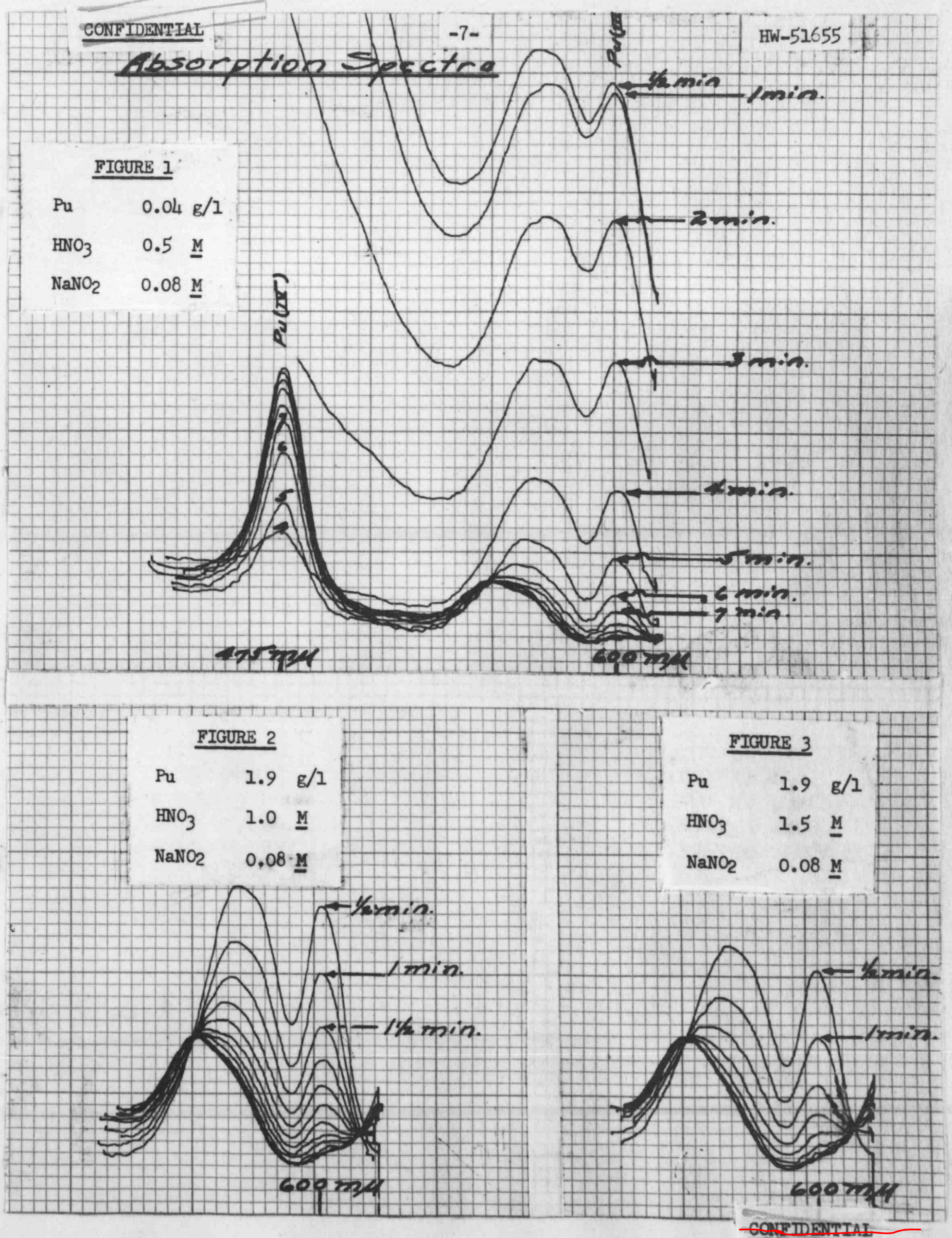


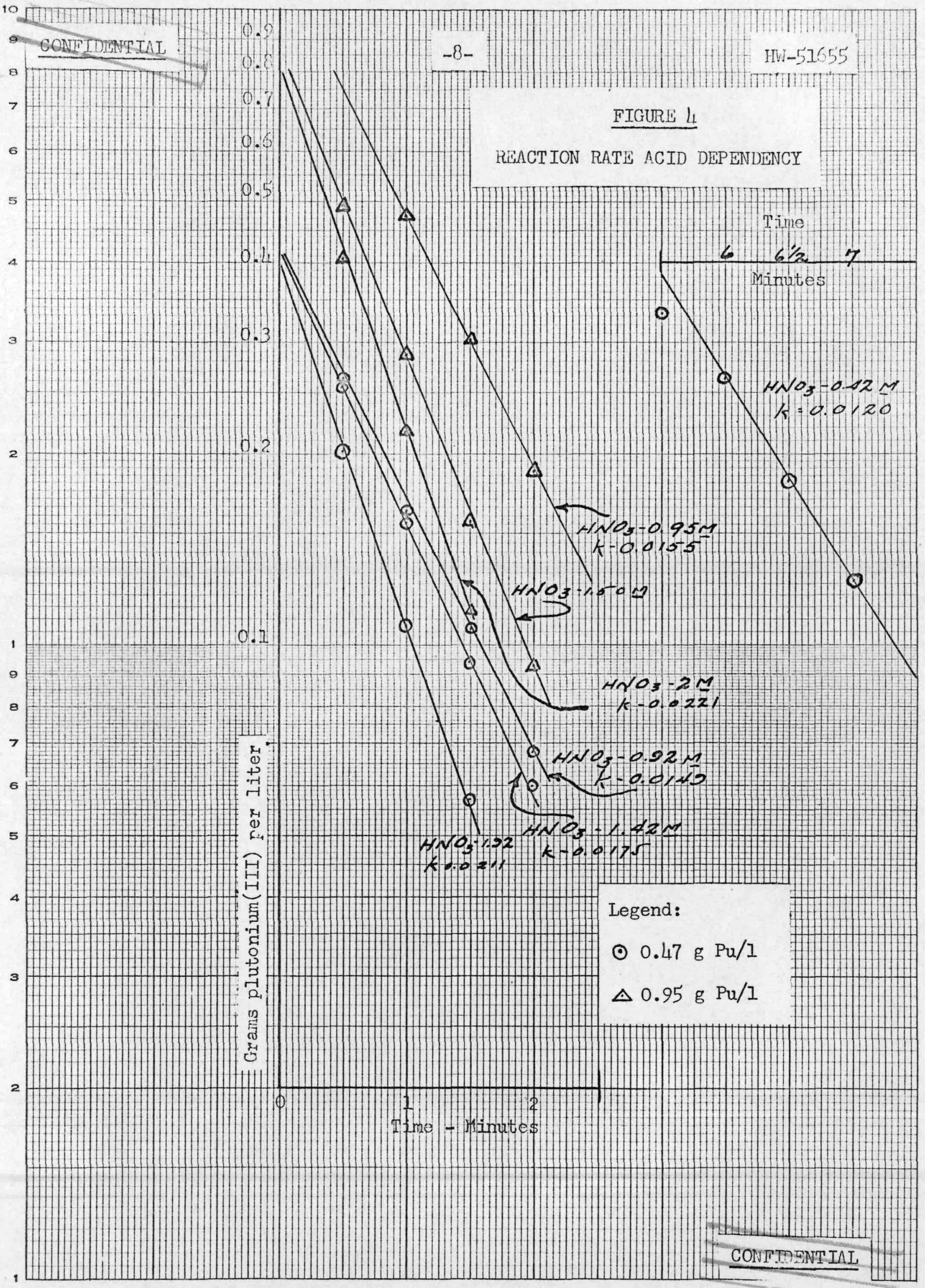




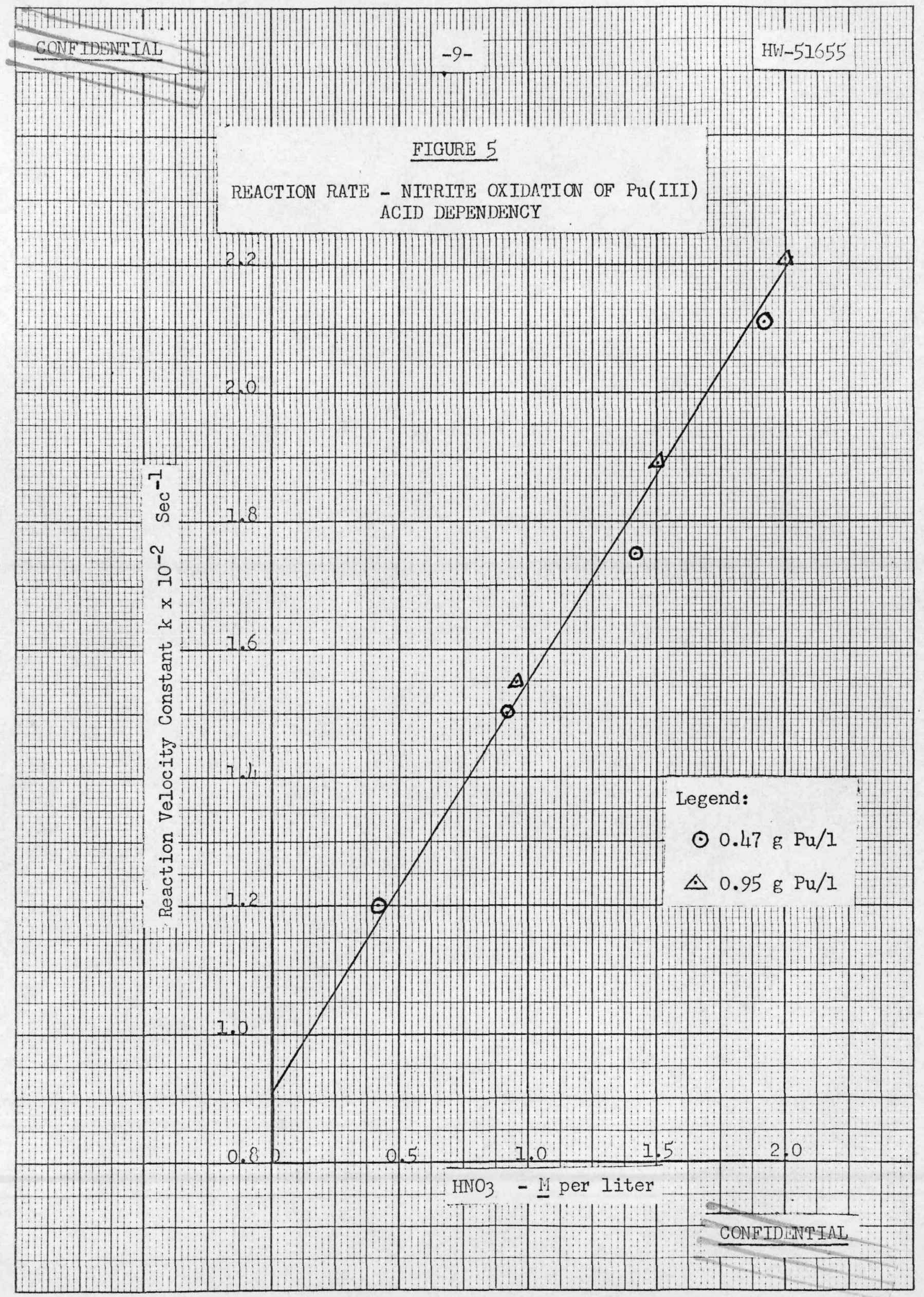




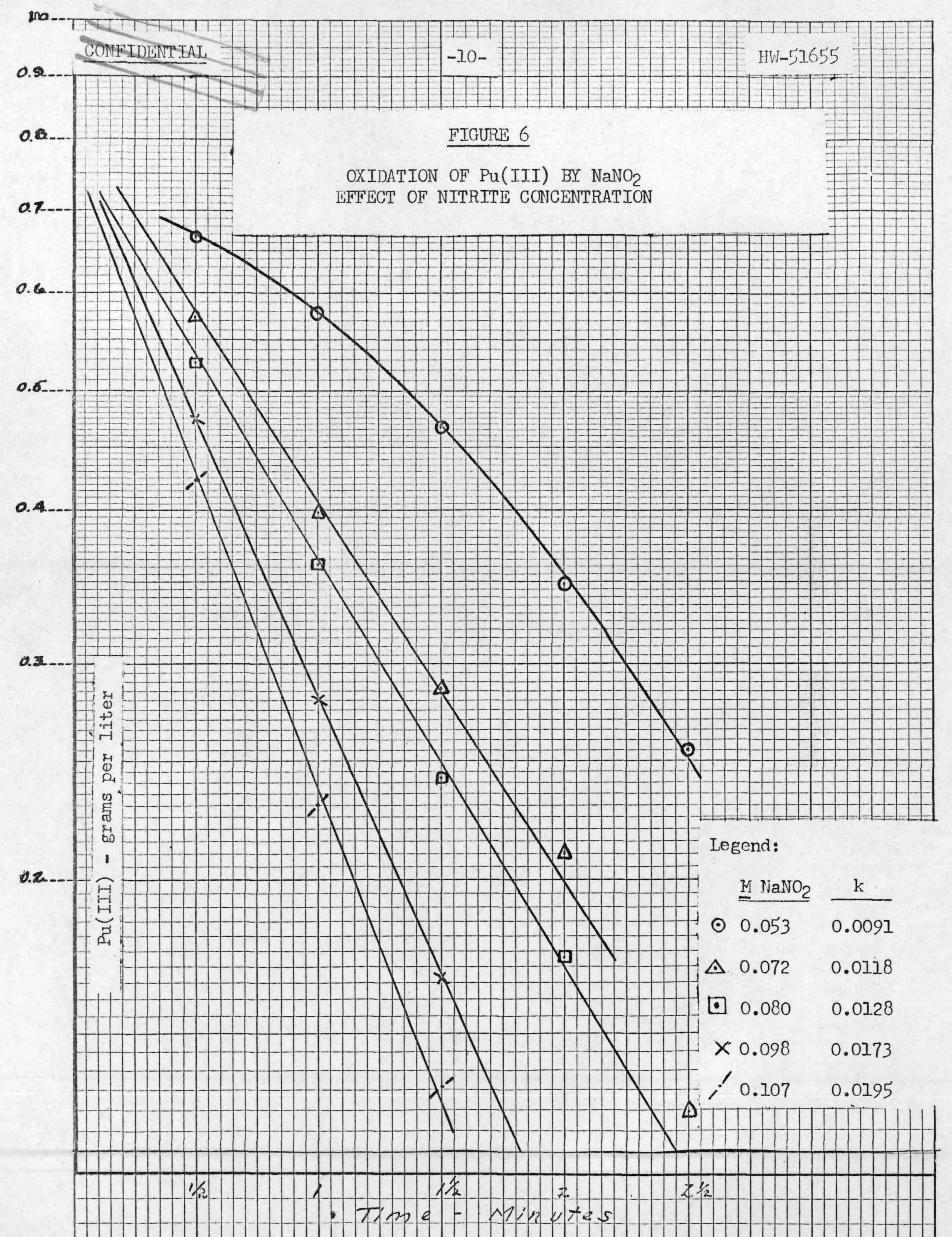




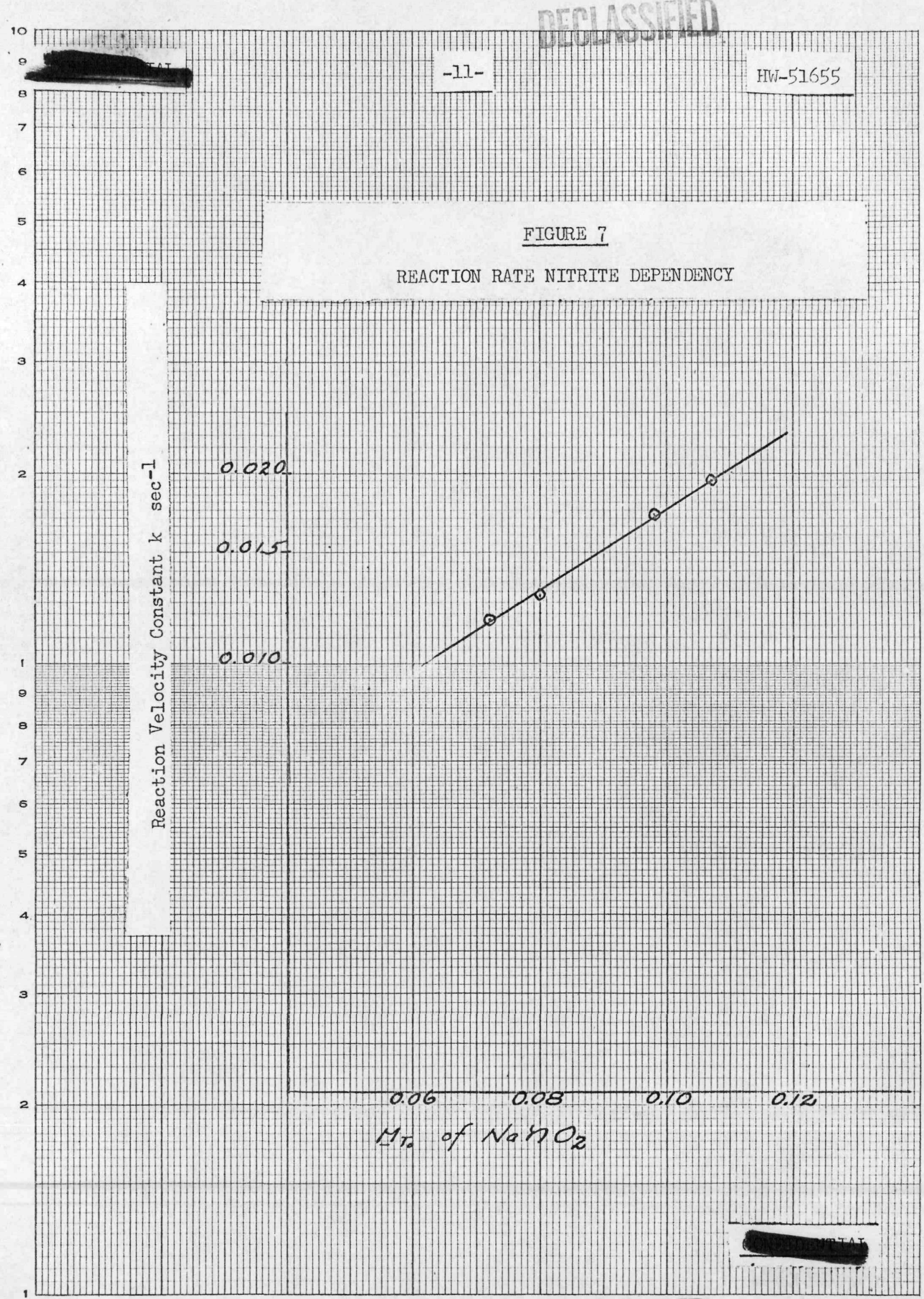




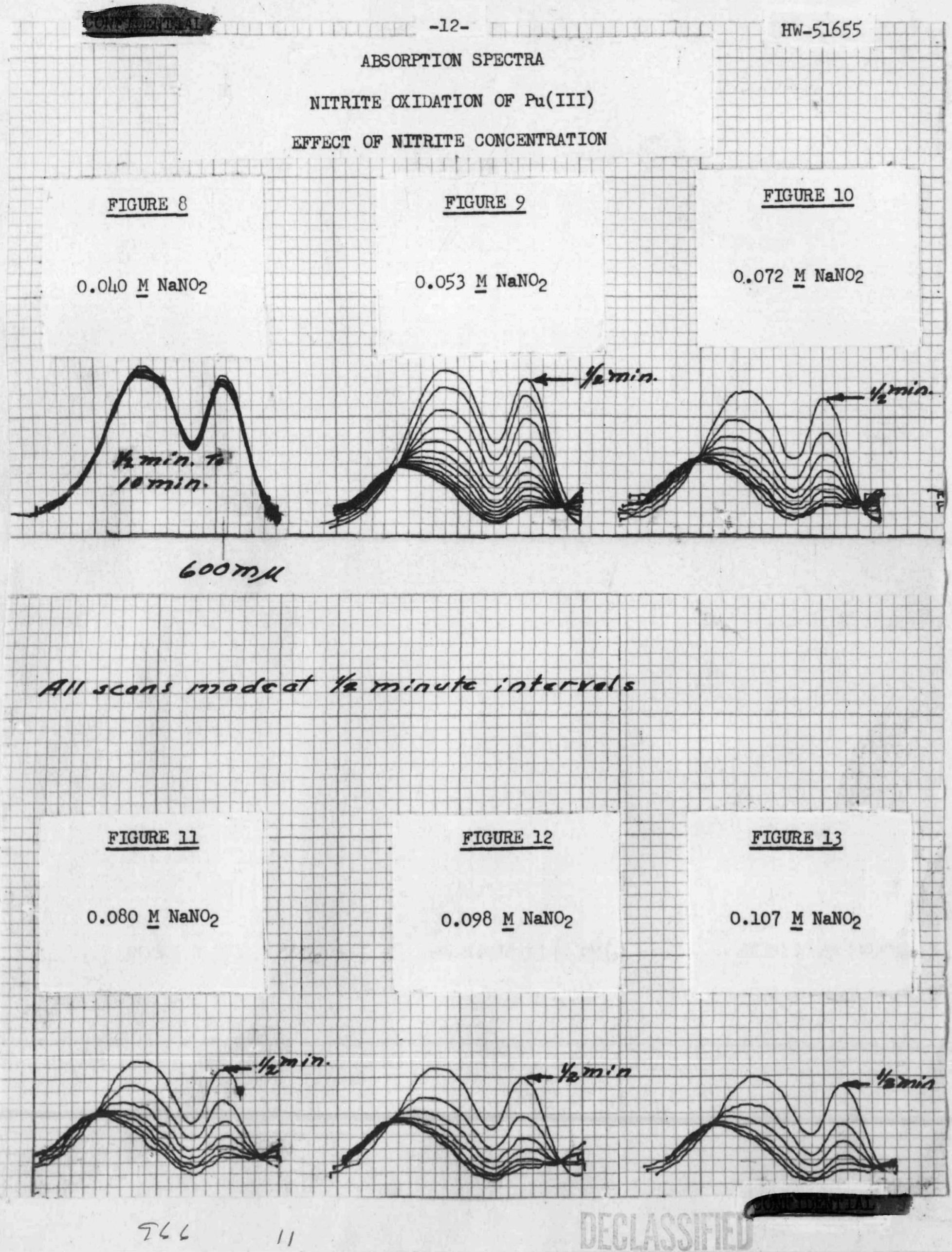

